\title{
Identification of the Barriers of Lean Construction Implementation in Construction Projects- A Review
}

\author{
Sakshi Gupta, Mujib Ahmad Ahmadi, Lalit Kumar
}

\begin{abstract}
In the current era of industrial and enterprise evolution, time and resource are the fundamental need of any industry. Utilizing the time and resource has always been the primary goal of especially a construction project in order to reduce the expenses, meet the project deadlines and accomplish the work successfully. Lean approach in the construction industry has been introduced to facilitate and manage such procedure to achieve the above-mentioned goals of a company. Construction industry has also adapted this approach under the title of lean construction to give boast in the process of construction projects by applying the lean construction techniques. In this research, we have tried to discover the lean construction barriers in the construction industry and limitations of implementing lean construction in construction industry worldwide. The barriers have been gathered through an extant literature survey and then concluded by defining them among different categories of professionals. It is concluded that overcoming the barriers would lead to less wastage in the construction industry and lead to more efficiency and productivity.
\end{abstract}

KEYWORDS- Lean construction, barriers, construction, industry, construction projects.

\section{INTRODUCTION}

The construction industry plays a significant role in any economy. Since this industry assemble a powerful chain of resources before, during and after its activities, it expresses a considerable part of the country's gross domestic product.

\section{Manuscript received May 21, 2020}

Sakshi Gupta, Assistant Professor, Department of Civil Engineering, Amity School of Engineering and Technology, Amity University Haryana, India (email: sgupta6@ggn.amity.edu)

Mujib Ahmad Ahmadi, Student, M.Tech Structural Engineering in the Department of Civil Engineering, Amity School of Engineering and Technology, Amity University Haryana, India.

Lalit Kumar, Assistant Professor, Department of Civil Engineering, Amity School of Engineering and Technology, Amity University Haryana, India.
On the other side, the benefit margins are lowering every year in construction industry because of rivalry, the resource cost and other economic issues, such as fees and taxes.

This clearly indicates that the construction industry demand to reform managerial tools and gain sufficient levels of efficiency and productivity to last its advantages [1] An easy explanation of lean construction was assumed in various literature [2-4]. Lean construction is an approach to plan production system to decrease waste of materials, time, and effort to produce the highest likely amount of value. According to the lean construction institute (LCI), "Lean construction is a managerial based production system to project delivery and that is mainly effective on multifaceted, indeterminate, and rapid projects" [5]. Lean construction is a way of designing and planning production system in a construction project. The foremost goal of lean construction is to minimize the duration of project, labors and wastage of material so as to produce the highest likely amount of value. It is a method that attempts to accomplish and enhance the construction method with optimized least cost and maximum possible amount of value by taking into consideration the customer requirements. The elementary concept of lean construction originated from the lean manufacturing principles that were executed by Toyota manufacturing successfully in their renowned in the year 1950's. Today, the construction industry is not as 'conventional' as it was 20 years ago, there are modern methods such as building information system and more collaborative variants of project delivery methods whose aim is to enhance the productivity. This would help to incline the construction industry more towards a lean industry. There is always scope for productivity improvements in construction industry. One way of contributing to the productivity betterment is to accomplish lean. Lean or lean thinking is used in the manufacturing industry for many years now. Lean have not been used in construction industry in a similar way like the manufacturing industry. So, there is a scope to take lean further in construction industry [6]. The prime objective of lean in construction projects is to use the resources such as labour and material in a way to get less waste and more productivity with few delays and with less price or, to remove the non-value activities. The lean construction approach is particularly compatible for complicated projects. Traditional method of completing a construction projects is to make optimal the projects at every activity and 
assuming that the customer value is increase in the design period. Optimizing each activity separately will not precede to make optimal project procedure. Because of the doubt in the procedure, particularly in complicate projects where many performers and activities are involved. Therefore, new production management including lean has developed. One of the most significant points with lean approach in construction projects are to optimize the subordination a modification between the tasks with different period such as design and construction. Actually, lean production does not comprise of any new philosophies of management techniques but only combines the prevailing principles into a new system. The primary goal of lean production is to avoid waste of time, money, equipment, etc. which has been explored through the extant literature in this work [7].

\section{WASTE REALTED TO LEAN CONSTRUCTION}

Waste is everything that uses resources but generate no value. The seven types of waste or "muda" has been recognized by Ohno [6], which are as follows:

- Overproduction

- Waiting

- Transportation

- Over processing

- Inventory

- Movement

- Defects

These wastes are sometimes abbreviated as 'TIMWOOD' for better remembrance.

Liker [7] mentioned one more waste i.e. waste of unused employee creativity. This leads to loss in various items such as time, idea, skills, developments, learning opportunities, etc. by not engaging or paying attention to the employees. For instance, construction companies hire their employees for physical work, but most of them seem to overlook the fact that staff members have the ability to think [8]. The fact is that by funding on staff's creativities, companies can remove the other seven wastes to endlessly advance their performance and productivity at the same time. The first five wastes i.e. Overproduction, Waiting, Transportation, Over processing and Inventory; refer to the flow of materials. The last two wastes i.e. Movement and Defects are related to work of labour.

\section{LITERATURE SURVEY}

Though lean construction is still in its beginning there are different sets of practices that have been planned, tested and implemented by various practitioners in the construction industry worldwide. the below segment discussed the different frameworks of lean construction that have been implemented. These involve lean construction as a socio-technical system which consider human and technical features; lean creativities in eight areas of the construction business. The lean construction controls, and the three leading models of lean construction as shortened by Green and May [10] from the perspective of policymakers in the business. Socio-technical system of lean construction design is well-defined as the mixture of practical and human subsystem into the identical work design. And it has contained lean manufacturing and lean construction with the similar goal, activities, and staff abilities but with divers' technical systems [11]. In developing countries, investigation is concerned with two main topics about lean construction [12]:

1. Feasibility study and investigation into awareness of lean construction.

2. Discovering the barriers to the implementation of lean construction.

Executing lean starts with recognizing the waste in construction, which agrees to the primary phase of Green and May's [10] outline of lean construction implementation. Feasibility study and awareness of lean, lean construction can be viewed as a planned choice when its application is placed in a new setting [13]. Senaratne and Wijesiri [15] applied suitability and acceptability examinations to accomplish that lean construction is appropriate and satisfactory in the Sri Lankan situation. Furthermore, Abduh and Roza [14] exposed that the huge Indonesian contractors have already applied "macro" lean construction principles (such as the rule of continuous development and promoting transparency). Yet when it comes to the "micro" principles of lean construction (such as the decrease of cycle time and variability), the big Indonesian contractors still lack understanding and the capability to apply principles and methods, because of insufficient ability to plan work-flow well. Barriers for Implementation of Lean Forbes et al [8] approved that the key problem to the application of lean in developing countries is that construction companies do not emphasize productivity and quality creativities. Furthermore, numerous barriers to the lean production under various management ideas identified.Like JIT, TQM, concurrent engineering, etc. in Uganda's construction business. The researchers [7] elaborated the barriers by grouping these into (1) barriers that powerfully effect workers' productivity, and (2) barriers that are easier to overcome. In Forbes et al [8]work, the challenges to application of lean was characterized under seven collections, namely: (1) skills and information related, (2) management related, (3) government related, (4) attitude related, (5) resource related, (6) logistics related, and (7) others. Low and Gao [15] discussed the possible barriers to applying the idea of JIT in the Chinese construction business from a project life-cycle perspective. A group of researchers [4] recognized many barriers to lean construction under various management ideas, including just in time, total quality management, concurrent engineering, and etc. the importance of finding barriers could be used to help researchers, practitioners and companies in Afghanistan construction industry to focus their attention and resources on the significant issues, vital to support the successful implementation of lean construction. The barriers to application of lean is characterized under six groups, specifically: (1) Management related, (2) Financial related, (3) Educational related, (4) Government related, (5) Technical related, (6) Human Attitudinal related. [16].

Based on a comprehensive literature review concerning to the barriers to the application the lean construction concept, this study classifies these barriers in to ten different groups as shown below [18].

- Fragmentation and subcontracting 
- Procurement and contracts

- Culture and human attitudinal issues

- Adherence to traditional management concepts due to time and commercial pressure

- Financial issuance

- Lack of top management commitment and support

- Design/ construction contrast

- Lack of adequate lean awareness/ understanding

- Educational issues

- Lack of customer- focused and process- based performance measurement systems

Based on the achievement of lean in manufacturing and growth of lean construction in countries around the world, the application of lean construction is currently discussed in India. The purpose of the study was to identify the barriers to successful application of lean construction in Indian construction industry. The data for this research was collected by a questionnaire survey from practitioners, such a project manager, architectural advisors and etc. after the data collection, the data analyzed to find the main barriers and lean principles are suggested to overcome these barriers [19]. After analyzing the data the significant barriers for implementing lean principles in construction business identified as

- Lack of exposure on the need to adopt lean construction

- Uncertainty in the supply chain

- The tendency to apply traditional management

- Culture \& human attitudinal issues (Mindset issues)

- Lack of commitment from top management

- Non- participative management style for workforce The summary of all literatures reviewed related to lean construction in different parts of the world have been presented in Table 1.

Table 1: Summary of the literatures studied related to lean construction and the barriers related to its implementation [References in table]

\begin{tabular}{|l|l|l|}
\hline $\begin{array}{l}\text { Author } \\
\text { (s) }\end{array}$ & Year & $\begin{array}{l}\text { Major barriers to } \\
\text { Implementing in different } \\
\text { construction in } \\
\text { countries around the world }\end{array}$ \\
\hline $\begin{array}{l}\text { Lim and } \\
\text { Jin }\end{array}$ & $\begin{array}{l}\text { - } \begin{array}{r}\text { Barrier found are: } \\
\text { i. Ineffective management } \\
\text { practices (Traditional) } \\
\text { ii. Just-in -time (JIT) delivery } \\
\text { of materials on site (IBS) }\end{array} \\
\text { iii. Cut and paste from pervious } \\
\text { project (Traditional and } \\
\text { IBS) }\end{array}$ \\
\hline $\begin{array}{l}\text { Sarhan } \\
\text { and Fox }\end{array}$ & $\begin{array}{l}\text { Barriers found in the study are: } \\
\text { Lack of satisfactory lean } \\
\text { awareness and considerate } \\
\text { Lack of top management } \\
\text { commitment } \\
\text { Culture and human } \\
\text { attitudinal problems }\end{array}$ \\
\hline
\end{tabular}

\begin{tabular}{|c|c|c|}
\hline $\begin{array}{l}\text { Devaki } \\
\text { and } \\
\text { Jayanthi }\end{array}$ & 2014 & $\begin{array}{l}\text { - Lack of experience on the } \\
\text { necessity to implement lean } \\
\text { construction } \\
\text { - Ambiguity in the supply chain } \\
\text { - Inclination for applying } \\
\text { traditional management } \\
\text { approaches. } \\
\text { - Culture \& human attitudinal } \\
\text { issues (Mindset issues) } \\
\text { - Lack of commitment from top } \\
\text { management officials. } \\
\text { - Non- } \\
\text { management style for } \\
\text { workforce }\end{array}$ \\
\hline $\begin{array}{l}\text { Tomas } \\
\text { Lindholm }\end{array}$ & 2014 & $\begin{array}{l}\text { - Lean concepts and tools could } \\
\text { be utilized in a larger amount } \\
\text { in construction projects } \\
\text { without difficulties. } \\
\text { - The concepts and tools } \\
\text { utilized in the car } \\
\text { manufacturing business. For } \\
\text { instance: just-in-time, other } \\
\text { ideas and tools have to be } \\
\text { added in the field of } \\
\text { construction to increase the } \\
\text { productivity and efficiency of } \\
\text { the construction projects. }\end{array}$ \\
\hline $\begin{array}{l}\text { Kumar } \\
\text { and } \\
\text { Kumar }\end{array}$ & 2014 & $\begin{array}{l}\text { The following barriers were } \\
\text { found through the study: } \\
\text { - Management } \\
\text { - Knowledge } \\
\text { - Conflicts } \\
\text { - Financial } \\
\text { - Employee } \\
\text { - Resources } \\
\text { - Past experience }\end{array}$ \\
\hline $\begin{array}{l}\text { Nifla K. } \\
\text { and } \\
\text { Reshma. P }\end{array}$ & 2014 & $\begin{array}{l}\text { - The analysis found the } \\
\text { following barriers: } \\
\text { i. Lack of lean awareness and } \\
\text { understanding } \\
\text { ii. Problems related with } \\
\text { Human attitude } \\
\text { iii. Commercial issues } \\
\text { iv. Lack of appropriate } \\
\text { training for the } \\
\text { employees } \\
\text { v. Lack of consultants } \\
\text { accessible for direction, } \\
\text { supervision } \\
\text { implementation } \\
\text { vi. Extensive implementation } \\
\text { time needed } \\
\text { vii. Issues with Employee } \\
\text { attitude and apropriate } \\
\text { viii. Lack of apd } \\
\text { communication between } \\
\text { client and contractor }\end{array}$ \\
\hline
\end{tabular}




\begin{tabular}{|c|c|c|c|c|c|}
\hline & & $\begin{array}{ll}\text { ix. } & \begin{array}{c}\text { Disintegration } \\
\text { subcontracting }\end{array}\end{array}$ & & & $\begin{array}{l}\text { positive impact on the } \\
\text { productivity. }\end{array}$ \\
\hline & & $\begin{array}{l}\text { x. Issues related with the } \\
\text { finances. } \\
\text { - The study revealed that nearly } \\
82.5 \% \text { of the companies that } \\
\text { were surveyed had very clear } \\
\text { idea about lean construction. }\end{array}$ & \multirow[t]{3}{*}{$\begin{array}{l}\text { Bajjou and } \\
\text { Chafi }\end{array}$} & \multirow[t]{3}{*}{2017} & \multirow{3}{*}{$\begin{array}{l}\text { - Construction practitioners in } \\
\text { Morocco found that lean } \\
\text { construction application will } \\
\text { add positive influence to the } \\
\text { Moroccan construction } \\
\text { projects. } \\
\text { - The concept will help in } \\
\text { augmenting the quality of the } \\
\text { projects that would advantage } \\
\text { from the most of the } \\
\text { developments according to the } \\
\text { output of data analysis } \\
\text { obtained by the researcher. } \\
\text { - Lean construction is a high } \\
\text { priority for the Moroccan } \\
\text { construction projects. }\end{array}$} \\
\hline $\begin{array}{l}\text { Pasha and } \\
\text { Naik }\end{array}$ & 2016 & $\begin{array}{l}\text { The analysis revealed that } \\
\text { about } 52.42 \% \text { of the surveyed } \\
\text { companies have utilized the } \\
\text { lean construction techniques } \\
\text { in the project and knows the } \\
\text { benefits of lean construction. }\end{array}$ & & & \\
\hline \multirow[t]{3}{*}{$\begin{array}{l}\text { Charhate } \\
\text { and Sinha }\end{array}$} & \multirow[t]{3}{*}{2016} & \multirow{3}{*}{$\begin{array}{l}\text { They found that following } \\
\text { barriers: } \\
\text { - Lack of lean awareness and } \\
\text { consideration. } \\
\text { - Lack of approach to lean } \\
\text { construction. } \\
\text { - Cultural and human } \\
\text { attitudinal issues } \\
\text { - Economical pressure } \\
\text { - Lack of proper training } \\
\text { - Lack of top management } \\
\text { - support Educational issues } \\
\text { - Lack of proper } \\
\text { communication between } \\
\text { client and contractor } \\
\text { - Financial issues }\end{array}$} & & & \\
\hline & & & $\begin{array}{l}\text { Hasan } \\
\text { Gokberk } \\
\text { Bayhan }\end{array}$ & 2018 & $\begin{array}{l}\text { - Lean practitioners point out to } \\
\text { clear comprehension of } \\
\text { practical needs in Lean to } \\
\text { best govern Lean application } \\
\text { procedure. } \\
\text { - Highlighted the point that the } \\
\text { lack of top management } \\
\text { support is the utmost } \\
\text { significant barrier for the } \\
\text { implementation of lean } \\
\text { concept in construction. }\end{array}$ \\
\hline & & & \multirow[t]{3}{*}{\begin{tabular}{|l} 
Ahmed \\
and Sobuz
\end{tabular}} & \multirow[t]{3}{*}{2019} & \multirow{3}{*}{$\begin{array}{l}\text { - The results identified } 41 \\
\text { challenges related to the lean } \\
\text { construction application in } \\
\text { the Bangladeshi construction } \\
\text { industry. } \\
\text { - The top challenges as } \\
\text { mentioned in the research } \\
\text { work are : } \\
\text { i. lack of awareness about lean } \\
\text { construction } \\
\text { ii. lack of skills, training and } \\
\text { lean methods, } \\
\text { iii. denial to change the current } \\
\text { culture, } \\
\text { iv. lack of management } \\
\text { promise, } \\
\text { v. disorganized and repeated } \\
\text { nature of the construction } \\
\text { projects. } \\
\text { - The study debated some } \\
\text { university appropriate } \\
\text { resolutions to defeat the } \\
\text { mentioned challenges. }\end{array}$} \\
\hline $\begin{array}{l}\text { Sarhan, } \\
\text { Xia and } \\
\text { Fawzia }\end{array}$ & 2017 & $\begin{array}{l}\text { The main issues that originate } \\
\text { the barriers were identified } \\
\text { as: } \\
\text { i. Traditional } \\
\text { implementation } \\
\text { ii. customer related, } \\
\text { iii. technological barrier, } \\
\text { iv. execution related } \\
\text { v. Information related } \\
\text { vi. cost-related barriers. } \\
\text { - Suggested answers to control } \\
\text { the main barriers. } \\
\text { - This research delivers a } \\
\text { world-wide overview of the } \\
\text { barriers to applying lean } \\
\text { construction. }\end{array}$ & & & \\
\hline $\begin{array}{l}\text { Ana } \\
\text { Reinbold }\end{array}$ & 2017 & $\begin{array}{l}\text { - The application of lean } \\
\text { construction in affordable } \\
\text { housing project has a great } \\
\text { positive impact. }\end{array}$ & & & \\
\hline
\end{tabular}

\section{DISCUSSION AND CONCLUSION}

On careful review of the literature, the following points have been found out in terms of barrier in the implementation of lean construction in various developing nations: 
i) Top Ranked Barriers Chosen by Civil Engineers Category

1. Lack of training \& awareness

2. Luck of Technical skills

3. Lack of government support

4. Inability to change the organizational culture

5. Lack of team work

ii) Top Major Barriers Chosen by Architect Category

1. Lack of Experience and information sharing

2. Lack of training \& awareness

3. Lack of technical skills

4. transparency

5. leadership

iii) Top Major Barriers Chosen by Academics Category

1. Logistic Problem

2. Luck of lean concept and understanding and knowledge

3. Conditions

4. Lack of training \& awareness

5. Cost of lean consultation.

iv) Top Major Barriers Chosen by Others stakeholders

1. Complexity of lean construction

2. Risk of top management support

3. Government bureaucracy and instability

4. Long implementation period

5. Lack of transparency

It is clear from the results that the top major barriers are related to the categories of Educational, Management and Technical barriers.

\section{FUTURE RECOMMENDATION}

Due to various constraints like limited outreach and time this study was limited to extant literature survey which can further be done for specific construction industries in developing countries such as Afghanistan. In future, researchers can take up both quantitative and qualitative approach of analysis and carry out a questionnaire based study to find the exact barriers in different countries and suggest remedial measures for the same. This will include site investigation and interviews with a greater number of participants to make the research more reliable and accurate.

\section{REFERENCES}

[1] S. P. L. Shang Gao, Lean Construction Management, Singapore: Springer, 2014.

[2] "Afghanistan GDP Annual Growth Rate2007-2019 Data," Trading Economics, 22 Jan 2019. [Online]. Available:

https://tradingeconomics.com/afghanistan/gdp-growt h-annual. [Accessed 12 April 2020].

[3] E. J, Rethinking Construction - the report of the construction task, London: Department of Environment, Transport and Regions, 1998.
[4]L. Koskela, The exploration towards a production theory and its application to construction, Espoo, Finland: Technical Reaserch Center of Finland, 2000.

[5] "Lean Construction Institute," LCI, 22 Feb 2020. [Online]. Available: https://www.leanconstruction.org/. [Accessed 12 May 2020].

[6]O. T, Toyota Production System: Beyond lage scale production, Cambridge: Productivity Press, 1988.

[3] L. J. K., The Toyota Way: 14 management principles from the world's greatest manufacturer., New York: Mc-Graw-Hill, 2004.

[7]D. P. F., The practices of management, New York: Harper \& Row Perennial Library, 1986.

[8]S. Emmitt, Design Management for Architects, Oxford: Blackwell, 2007.

[9]S. D. \&. M. S. C. Green, "Arenas of enhancement, models of diffusion and the meaning of "leanness"," in Lean Construction , Building Researchand Information, 2005, pp. 498-511.

[10]O. Paez, "Human Factors and Ergonomics in Manufacturing," in Moving from lean manufacturing to lean construction, 2005, pp. 233-245.

[11]L. H. ,. A. S. M. \&. B. M. Forbes, "Adapting lean construction theory for practical application in developing countries," in 1st CIB W107 International Conference, Stellenbosch, 2002.

[12]S. \&. W. D. Senaratne, "Lean Construction as strategic opinion- Testing its suitability and acceptibility in Sri Lanka," Lean Construction Journal, pp. 34-48, 2008.

[13]M. \&. R. H. A. Abduh, "Indonesian Contractors : readiness towards lean construction," in 14th Annual Conference of the international group of lean construction, Santiago, 2006.

[14]G. Ballard, The last planner system of production control, Birmingham: Department of Civil Engineering, University of Birmigham, 2000.

[15]S. D. E. J. Hasan Gokberk Bayhan, "Enablers and Barriers of Lean Implementation in Construction Projects," IOP Science, 2019.

[16]V. L. A. Jin, "Lean Construction : Knowledge and Barriers in Implementing into Malaysian Construction Industry," Universiti Teknologi Malaysia, Kuala Lampur, 2008.

[17]S. X. \&. F. A., "Barriers to Implementing Lean Construction in the UK," University of Plymouth, UK, Plymouth, 2013.

[18]D. M. P. \&. R. Jayanthi, "Barriers to Implementation of Lean Principles in the Indian Construction Industry," International Journal of Engineering Research \& Technology (IJERT), vol. 3, no. 5, pp. 1189-1192, 2014.

[19]T. Lindholm, "Lean in Construction Projects," KTH Building Technology, Stockholm, 2014.

[20]R. K. \&. D. V. Kumar, "Barriers in Implementation of Lean Manufacturing System in Indian industry: A Survey," International Journal of Latest Trends in Engineering and Technology (IJLTET), vol. 4, no. 2, pp. $243-251,2014$. 
[21]N. K. \&. R. P, "Barriers for Implementing Lean Concepts in Indian Construction Industry," International Journal of Engineering Research \& Technology (IJERT), vol. 8, no. 5, pp. 405 - 407, 2019.

[22]S. M. S. P. \&. B. Naik, "An Analysis of Lean Construction Practices in Tamilnadu Construction Industry," International Journal of Innovative Research in Science, Engineering and Technology, vol. 5, no. 9, pp. 16391 - 16398, 2016.

[23]D. S. C. \&. M. S. Vinaya D. More, "Lean Construction Techniques in Indian Construction Industry: Some Analysis," International Journal of Civil Engineering Research., vol. 7, no. 1, pp. 59 - 65, 2016.

[24]B. X. S. F. A. K. A. O. Jamil Sarhan, "Barriers to implementing lean construction practices in the Kingdom of Saudi Arabia (KSA) construction industry," Construction Innovation, vol. 18, no. 2, pp. 246 - 272, 2018.

[25]A. Reinbold, "Benefits of Lean Construction for Affordable Housing," Metropolia UAS and HTW Berlin, Berlin, 2017.

[26]A. C. Mohamed Saad Bajjou, "Towards Implementing Lean Construction in the Moroccan Construction Industry: Survey Study,” IEEE, 2018.

[27]H. G. Bayhan, "Enablers and Barriers of Lean Implementation in Construction Projects," IOP Conference Series, vol. 471, no. 2, 2019.

[28]S. Ahmad, "Challanges of implementing lean construction in indusstry in Bangladesh," Emerland Publishing, 2019.

[29]C. \&. A. P. Karlsson, "Assessing changes towards lean production," International Journal of Operation and Production Management, vol. 2, no. 16, pp. 24-41, 1996.

\section{ABOUT THE AUTHORS}

Sakshi Gupta, is presently working as Assistant Professor, Department of Civil Engineering, Amity School of Engineering and Technology, Amity University Haryana, India. Her areas of interest include construction technology and management, BIM, concrete technology, Soft computing techniques in Civil Engineering applications and sustainable construction. She has published more than 40 research articles, paper, book chapters and books of National and International repute. She is the editorial as well as reviewer board member of many international journals.

Mujib Ahmad Ahmadi is the student of M.Tech Structural Engineering in the Department of Civil Engineering, Amity School of Engineering and Technology, Amity University Haryana, India.

Lalit Kumar, is working as Assistant Professor, Department of Civil Engineering, Amity School of Engineering and Technology, Amity University Haryana, India. His area of specialization includes design and analysis of roads, pavements, culverts, buildings, etc. He is competent in various software related to transportation engineering. He has published various papers in journals of national and international repute. 